\title{
CARBON BLACK EXPOSURE AND
}

\section{CARDIOPULMONARY EFFECTS AMONG EGYPTIAN WORKERS}

\author{
By \\ ${ }^{1}$ EL Okda EL and ${ }^{2}$ Maraghy A \\ ${ }^{1}$ Department of Community, Environmental and Occupational Medicine, \\ ${ }^{2}$ Chest Department, Ain Shams University, Cairo, Egypt
}

\begin{abstract}
:
Introduction: Growing evidence suggests that occupational exposure to carbon black may be a risk factor to the cardiovascular and respiratory systems. Objectives: To spotlight cardiopulmonary changes among workers exposed to carbon black, to find out different risk factors which may increase the health hazards and to determine the most effective intervention strategy to limit health hazards of carbon black exposure. Materials and Methods: A cross sectional study was done in carbon black factory in Borg Elarab ,Alexandria. The studied group was subjected to a questionnaire including detailed occupational, present and past histories. General examination was done, blood pressure was measured in erect and supine positions and average was taken. Mean arterial blood pressure was calculated. Investigations were done including: $\mathrm{CBC}$, pulmonary function testing (FVC and FEV1) and Plain chest x- ray. Results: the current study detected that DBP was higher among highly exposed group ( 80.7 \pm 9$)$ compared to moderately exposed (77.6 \pm 9 ) and unexposed (76.5 \pm 8 ) (statistically significant ). Mean arterial blood pressure was higher among highly exposed (95 \pm 8.4$)$ and moderately

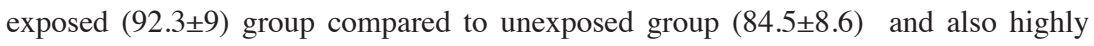
exposed departments compared to moderately exposed with significant difference. As

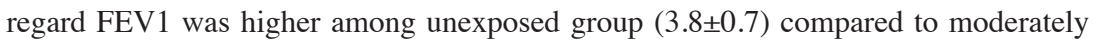
exposed (3.5 \pm 0.8$)$ and highly exposed (3.4 \pm 0.9$)$ with statistically significant difference $(\mathrm{p}<0.05)$. Also FVC was higher among unexposed group $(4.8 \pm 0.7)$ compared to moderately exposed group (4.6 \pm 0.9$)$ which was slightly higher than highly exposed group (4.3 \pm 0.8$)$ with statistically significant difference. Both $\%$ of FEV1/FVC and
\end{abstract}


FVC/PVC were higher among unexposed group (84.6 \pm 7.6$)$ and (89 \pm 7.6$)$ compared to heavily exposed (77.6 \pm 9$)$ and $(85.3 \pm 9)$ and moderately exposed $(80 \pm 5)$ and $(87 \pm 7)$ respectively with statistically significant difference. As regard the effect of work duration and smoking index; statistically significant inverse correlation was detected between all pulmonary function tests (PFT) versus duration of exposure among highly exposed group. Among moderately exposed group there is a statistically significant inverse correlation between FVC, FEV1 and FVC/PVC but no significant correlation could be detected versus FEV1/FVC. Conclusion: Carbon black exposure plays an important role in deterioration of pulmonary functions and elevation of diastolic and mean arterial blood pressure. Smoking plays a synergistic effect together with carbon black in induction of pulmonary and blood pressure changes.

Key words: Carbon black, Blood pressure risk factors, pulmonary function tests, Smoking index,

\section{Introduction}

Exposure to particulate air pollution has been associated with cardiovascular morbidity and mortality in numerous epidemiologic studies (Brook 2008; Pope et al. 2004).Carbon black (CB), a combustion by-product, is a widely used marker of traffic pollution and has been linked to cardiac and ventricular arrhythmias (Rich et al. 2005), STsegment depression (Gold et al. 2000), decreased flow-mediated vascular reactivity (O'Neill et al. 2005), lowered heart rate variability (Schwartz et al. 2005), and increased cardiovascular mortality (Maynard et al. 2007). Growing evidence suggests that trafficrelated pollution, including $\mathrm{CB}$, may be driving the cardiotoxic effects observed in response to air pollution exposures. A few recent studies have examined associations between particles and blood pressure (BP), and although positive associations have been observed (Auchincloss et al. 2008; Ibald-Mulli et al. 2001; Zanobetti et al. 2004), but also inverse (Harrabi et al. 2006) and null (Jansen et al. 2005; Madsen and Nafstad 2006) associations have also been reported.

Carbon black are very fine powdered forms of elemental carbon and are manufactured by several different processes which all involve the controlled vapour phase pyrolysis of liquid or gaseous hydrocarbons (Gardiner, 2006). Currently, the oil furnace process accounts for more than $95 \%$ of world production, with most of the carbon black being used in the production of tyres, iron and steel industries (Kupper et al. 2006). The main concern about exposure to carbon black is the ultrafine size of 
the primary particle $(10-500 \mathrm{~nm})$ and their aggregates (80-800 nm), although no research has been undertaken to evaluate the size distribution of the agglomerates found in occupational environments. The studies evaluating respiratory morbidity and mortality started in the early 1950s. Also, known carcinogenic polyaromatic hydrocarbons (PAHs) are adsorbed onto the surface of carbon black, although evidence of their bioavailability is equivocal (Gardiner, 2006). Recently, the International Agency for Research on Cancer (IARC) classified carbon black as a possible human carcinogen (2B) based on animal evidence (Van Tongeren, 2000). A detailed review of the literature on the respiratory health effects of occupational exposure to carbon black has been published by Gardiner (1995). He reported that exposure-response relations were evident for small opacities on chest radiographs, forced expiratory volume in 1 second (FEV1) and forced midexpiratory flow (FEF25\%-75\%), and the symptoms of chronic bronchitis.

Since the review by Gardiner, several researches have been published from studies in Germany and Poland (Küpper et al 2006) reported evidence of a relation between exposure to carbon black and lung function, albeit only among smokers, and hence a synergistic effect between smoking and exposure to dust was postulated. Szozda reported cases of hypertension and pneumoconiosis among Polish carbon black workers (Szozda, 2005)

This work describes the results of the cross sectional analyses of respiratory health and blood pressure changes among carbon black workers in Alexandria, Egypt.

\section{Objectives}

- To spotlight cardiopulmonary effects among workers exposed to carbon black

- To find out different risk factors which may increase the health hazards?

- To determine the most effective intervention strategy to limit health hazards of carbon black exposure

\section{Materials and Methods}

Type of the study: Cross sectional study

Sample size justification: sample size was calculated guided by prevalence of pulmonary disorders among carbon black exposed workers. 
Manual formula used for this purpose which depends on power of the used test to be $80 \%$, with beta error $20 \%$. Confidence level was $95 \%$ and hence z-score of 1.96 and accepted margin of error to be 0,05 .

Total sample calculated was 410 workers

Subjects: 410 workers in carbon black factory in Alexandria in Egypt were enrolled in this study and they are further classified into 3 subgroups according to the level of exposure. Highly exposed workers were included in packaging and main production and raw material processing (100 workers), moderately exposed workers in maintenance and final production (250 workers). The third group was unexposed group which include 60 administration, projects and security workers.

Sampling plan: Workers were allocated to this study by simple random selection according to their ID numbers which were used as a sample frame

Exclusion criteria: Workers who have a past history of pulmonary or cardiovascular disorders as bronchitis, hypertension and ischemic heart disease were excluded from this study.

Methodology: All workers were subjected to a detailed questionnaire including occupational, past and present histories of any disease, any treatment taken, and special habits especially smoking. General examination was done, blood pressure was measured in erect and supine positions and the average was taken. Mean arterial blood pressure were calculated using the following formula (diastolic x 2) \pm (systolic/3).

Smoking index was calculated by multiplying the number of cigarettes per day versus duration of smoking in years

Investigations: The studied groups were subjected to:

- $\quad$ CBC (complete blood count)

- Pulmonary function testing using spirometry for measurement of FVC and FEV1 with calculation of FVC/PVC and FEV1/FVC guided by software of the instrument. Three trials were done for each worker and the average was taken

- Plain chest x- ray .

\section{Ethical}

Confidentiality completely guaranteed and verbal consent was taken from all workers 
enrolled in this study. Any detected cases will be referred according to the diagnosis for proper management.

Time frame: the study started at April 2013 and finished at December 2013

\section{Statistical Study}

Analysis of data was done by IBM computer using SPSS (statistical program for social science version 16) as follows: Description of quantitative variables as mean, SD and range, description of qualitative variables as number and percentage .Chi-square test was used to compare qualitative variables between groups. Unpaired t-test was used to compare quantitative variables, in parametric data $(\mathrm{SD}<50 \%$ mean). Correlation co-efficient test was used to rank variables versus each other positively or inversely .P value $>0.05$ insignificant, $\mathrm{P}<0.05$ significant and $\mathrm{P}<0.01$ highly significant (Clinton, 1992).

\section{Results}

The current study shows that average age was $(33.6 \pm 12,37.5 \pm 13$ and $35 \pm 10$ ) among the 3 studied groups respectively, all examined workers were male, with average work duration of $8.5 \pm 3,6.7 \pm 2.2$ and $7 \pm 2$ respectively with no statistically significant difference between the studied groups ( $\mathrm{p}$ value $>0.05$ ). As regard smoking, current smokers were $(24 \%, 24.4 \%$ and $35 \%$ ) of the 3 groups respectively with no significant difference in between $\mathrm{p}>0.05$. 
Table (1) Comparison between studied groups as regard blood pressure

\begin{tabular}{|c|c|c|c|c|c|}
\hline Variables & $\begin{array}{l}\text { Highly exposed } \\
\qquad \mathbf{N}=\mathbf{1 0 0}\end{array}$ & $\begin{array}{c}\text { Moderately } \\
\text { exposed } \mathrm{N}=250\end{array}$ & $\begin{array}{c}\text { Unexposed } \\
\qquad \mathbf{N}=60\end{array}$ & $\mathbf{P}$ & LSD \\
\hline SBP & $1 r \pm 1 \int \varepsilon, v$ & $15 \pm 15$ & $r \cdot \pm 1 r r, q$ & $\cdot, \Gamma \varepsilon$ & \\
\hline DBP & $q \pm \Lambda \cdot, v$ & $q \pm V V, 1$ & $\Lambda \pm \vee 1,0$ & $* * \cdot, \cdot r$ & $\begin{array}{l}\text {-Highly } \\
\text { exp. Versus } \\
\text { unexposed } \\
(\cdot, \cdot r) \\
\text {-Highly } \\
\text { exp. Versus } \\
\text { moderate }(\cdot, \cdot r)\end{array}$ \\
\hline МАВР & $\Lambda, \Sigma \pm 90$ & $9 \pm 9 r, r$ & $\wedge, 1 \pm \wedge \varepsilon, 0$ & $* * \cdot, \ldots$ & $\begin{array}{l}\text {-Highly } \\
\text { exp. Versus } \\
\text { unexposed } \\
(\cdot, \cdot r) \\
\text {-Highly } \\
\text { exp. Versus } \\
\text { moderate }(\cdot, \cdot r) \\
\text {-Moderate } \\
\text { versus } \\
\text { unexposed } \\
(\cdot, \cdot 1)\end{array}$ \\
\hline
\end{tabular}

$\mathrm{LSD}=$ post hoc test (least significant difference)

SPB: Systolic blood pressure

DBP: Diastolic blood pressure

MABP: Mean arterial blood pressure

**: highly significant

Table (1) shows that DBP was higher among highly exposed group ( 80.7 \pm 9 ) compared to moderately exposed (77.6 \pm 9$)$ and unexposed (76.5 \pm 8$)$ with statistically significant $(\mathrm{p}<0.05)$. Mean arterial blood pressure was higher among highly exposed $(95 \pm 8.4)$ and moderately exposed (92.3 \pm 9$)$ group compared to unexposed

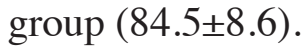




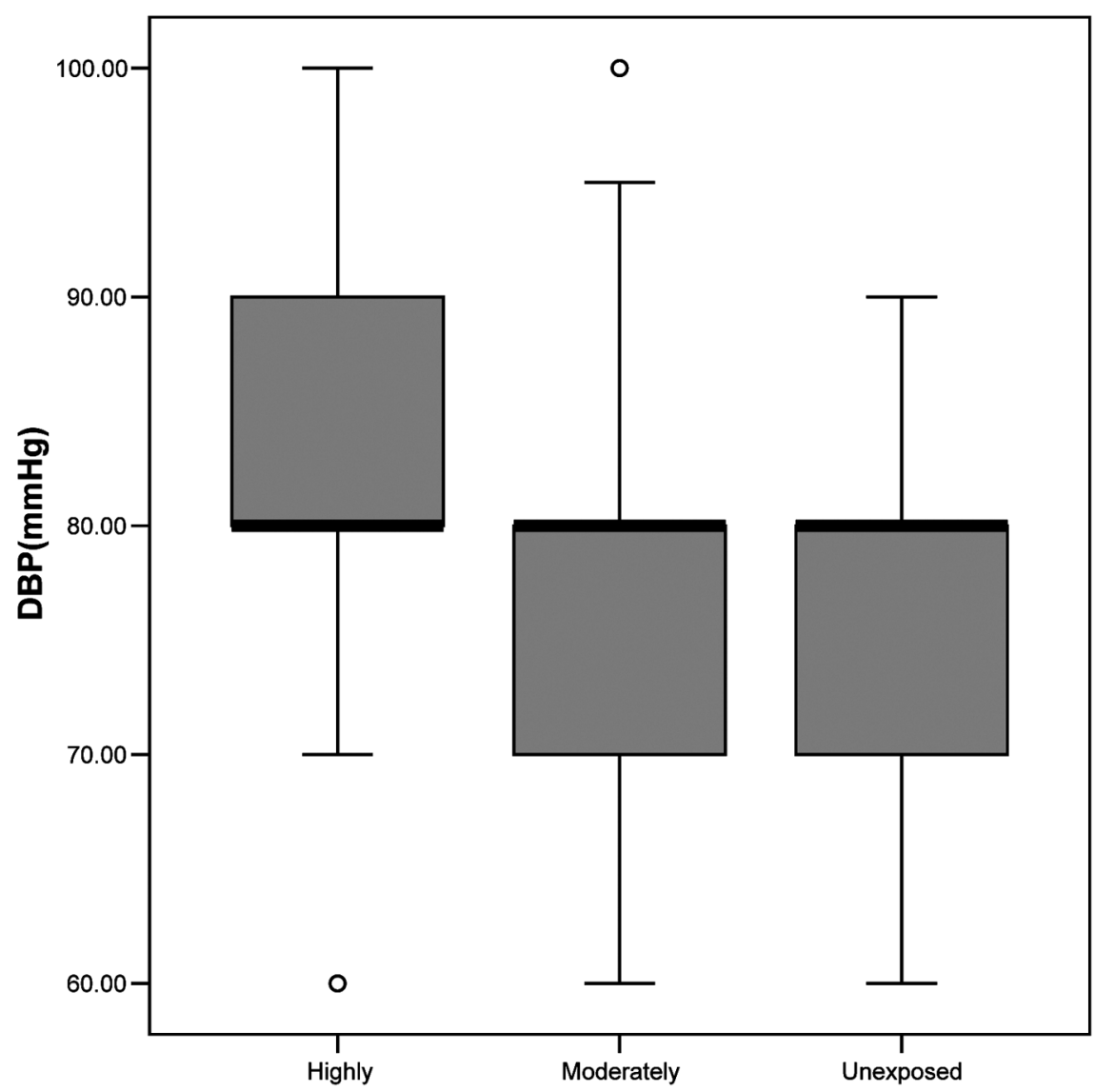

Figure (1) Comparison between the studied groups as regard DBP

Figure (1) shows that highly exposed group had the highest median DBP compared to the other two groups. 
Table (2) Comparison between the studied groups as regard History, Clinical examination and Investigations.

\begin{tabular}{|c|c|c|c|c|c|}
\hline Variables & $\begin{array}{l}\text { Highly } \\
\text { exposed } \\
\mathrm{N}=100\end{array}$ & \begin{tabular}{|c|} 
Moderately \\
exposed \\
$\mathrm{N}=250$
\end{tabular} & $\begin{array}{l}\text { Unexposed } \\
\qquad \begin{array}{l}\mathrm{N}=60\end{array}\end{array}$ & $\mathbf{X}^{2}$ & $\mathbf{p}$ \\
\hline $\begin{array}{l}\text { Past history } \\
\text { Negative } \\
\text { Positive }\end{array}$ & $\begin{array}{c}(93 \%) 93 \\
(7 \%) 7\end{array}$ & $\begin{array}{c}(\% 94.8) 237 \\
(5.2 \%) 13\end{array}$ & $\begin{array}{c}(95 \%) 57 \\
(5 \%) 3\end{array}$ & 0.98 & 0.91 \\
\hline $\begin{array}{l}\text { Chest examination } \\
\text { NAD } \\
\text { Wheezy chest }\end{array}$ & $\begin{array}{l}(90 \%) 90 \\
(10 \%) 10\end{array}$ & $\begin{array}{c}(98.8 \%) 247 \\
(1.2 \%) 3\end{array}$ & $\begin{array}{c}(98.3 \%) 59 \\
(1.7 \%) 1\end{array}$ & 0.7 & 0.84 \\
\hline $\begin{array}{l}\text { Chest x-ray } \\
\text { Negative } \\
\text { Increased BVM } \\
\text { Cardiomegally }\end{array}$ & $\begin{array}{c}(62.9 \%) 61 \\
(32 \%) 31 \\
(5.2 \%) 5\end{array}$ & $\begin{array}{c}(83.1 \%) 182 \\
(16.9 \%) 37 \\
0\end{array}$ & $\begin{array}{c}(74.1 \%) 40 \\
(24.1 \%) 13 \\
(1.9 \%) 1\end{array}$ & 29 & $* * 0.000$ \\
\hline $\begin{array}{l}\text { CBC } \\
\text { NAD } \\
\text { Lymphocytosis } \\
\text { Lymphocytosis \& neutrophelia } \\
\text { Leukopenea } \\
\text { Neutrophelia }\end{array}$ & $\begin{array}{c}(93 \%) 93 \\
0 \\
(2 \%) 2 \\
(2 \%) 2 \\
(2 \%) 2\end{array}$ & $\begin{array}{c}(89.4 \%) 219 \\
(4.5 \%) 11 \\
(1.6 \%) 4 \\
(3.3 \%) 8 \\
(1.2 \%) 3\end{array}$ & $\begin{array}{c}(91.5 \%) 54 \\
(1.7 \%) 1 \\
(1.7 \%) 1 \\
(3.4 \%) 2 \\
(1.7 \%) 1\end{array}$ & 6.1 & 0.63 \\
\hline
\end{tabular}

NAD: No abnormality detected

BVC: Broncho vascular markings
CBC: Complete blood count

**: highly significant

Table (2) shows that lung congestion (increased broncho vascular markings) and cardiomegally were more frequent among highly exposed group compared to other two groups with statistically significant difference. On the other hand no statistically significant difference could be detected between the 3 studied groups in comparing the clinically or laboratory findings. 
Table (3) Comparison between studied groups as regard pulmonary function tests.

\begin{tabular}{|c|c|c|c|c|l|}
\hline Variables & $\begin{array}{c}\text { Highly } \\
\text { exposed } \\
\text { N= 100 }\end{array}$ & $\begin{array}{c}\text { Moderately } \\
\text { exposed } \\
\text { N=250 }\end{array}$ & $\begin{array}{l}\text { Nnexposed } \\
\text { N=60 }\end{array}$ & $\mathbf{P}$ & \multicolumn{1}{|c|}{ LSD } \\
\hline FVC & $4.3 \pm 0.8$ & $4.6 \pm 0.9$ & $4.8 \pm 0.7$ & $0.000^{* *}$ & $\begin{array}{l}\text {-Highly exp. Versus } \\
\text { unexposed (0.01) } \\
\text {-Highly exp. Versus } \\
\text { moderate (0.04) } \\
\text {-moderate versus unex- } \\
\text { posed (0.03) }\end{array}$ \\
\hline FEV1 & $3.4 \pm 0.9$ & $3.5 \pm 0.8$ & $3.8 \pm 0.7$ & $0.000^{* * *}$ & $\begin{array}{l}\text {-Highly exp. Versus } \\
\text { unexposed (0.04) } \\
\text {-moderate versus unex- } \\
\text { posed (0.05) }\end{array}$ \\
\hline $\begin{array}{c}\text { FEV1/ } \\
\text { FVC }\end{array}$ & $77.6 \pm 10$ & $80 \pm 5$ & $84.6 \pm 8$ & $0.000^{* * *}$ & $\begin{array}{l}\text {-Highly exp. Versus } \\
\text { unexposed (0.001) } \\
\text {-Highly exp. Versus } \\
\text { moderate (0.01) } \\
\text {-moderate versus unex- } \\
\text { posed (0.02) }\end{array}$ \\
\hline FVC/PVC & $85.3 \pm 9$ & $87 \pm 7$ & $89 \pm 7.6$ & $0.001^{* * *}$ & $\begin{array}{l}\text {-Highly exp. Versus } \\
\text { unexposed (0.04) } \\
\text {-moderate versus unex- } \\
\text { posed (0.03) }\end{array}$ \\
\hline
\end{tabular}

$\mathrm{LSD}=$ post hoc test (least significant difference)

**: highly significant

Table (3) shows that both FEV1 and FVC were lower among highly and moderately exposed groups compared to unexposed with statistically significant difference. Both \% of FEV1/FVC and FVC/PVC were lower among highly and moderately exposed groups compared to unexposed with statistically significant difference 
Table (4) Correlation between blood pressure and PFT versus work duration in years among the studied groups.

\begin{tabular}{|l|c|c|c|c|c|c|}
\hline Variables & \multicolumn{2}{|c|}{$\begin{array}{c}\text { Highly exposed } \\
\text { Duration }\end{array}$} & \multicolumn{2}{c|}{$\begin{array}{c}\text { Moderately } \\
\text { exposed } \\
\text { Duration }\end{array}$} & \multicolumn{2}{c|}{$\begin{array}{c}\text { Unexposed } \\
\text { Duration }\end{array}$} \\
& r & \multicolumn{2}{|c|}{$\mathbf{P}$} & \multicolumn{2}{c|}{ r } & \multicolumn{2}{c|}{ P } \\
\hline SBP & 0.23 & 0.45 & 0.19 & 0.13 & 0.06 & 0.59 \\
\hline DBP & 0.11 & 0.23 & 0.17 & 0.18 & 0.04 & 0.27 \\
\hline MABP & 0.09 & 0.32 & 0.01 & 0.88 & 0.03 & 0.58 \\
\hline FVC & -0.35 & $0.000^{* *}$ & -0.23 & $0.000^{* *}$ & 0.09 & 0.45 \\
\hline FEV1 & -0.34 & $0.00 * *$ & -0.22 & $0.000^{* *}$ & -0.12 & 0.11 \\
\hline FEV1/FVC & -0.19 & $0.04 *$ & 0.10 & 0.11 & -0.16 & 0.10 \\
\hline FVC/PVC & -0.27 & $0.000 * *$ & -0.19 & $0.002 *$ & -0.02 & 0.30 \\
\hline
\end{tabular}

*: Significant

**: highly significant

Table (4) shows statistically significant inverse correlation between all PFT versus duration of exposure among highly exposed group. On studying the moderately exposed group there is a statistically significant inverse correlation between FVC, FEV1 and FVC/PVC but no significant correlation could be detected versus FEV1/FVC. On the other hand there is no statistically significant correlation could be detected between PFT versus duration of work among unexposed group. 


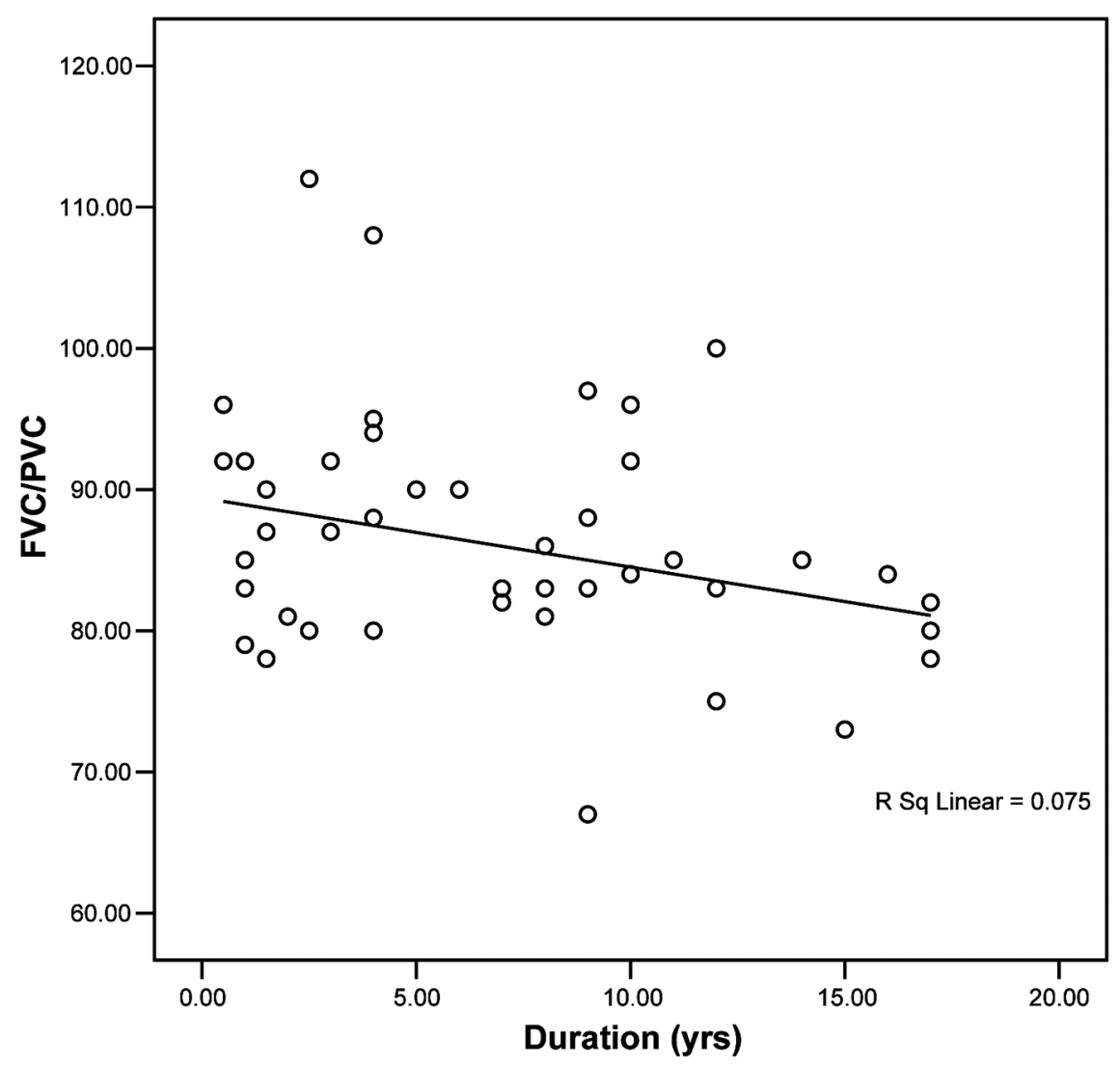

Figure (2) Correlation between duration of exposure in years versus $\mathrm{FVC} /$ PVC among highly exposed group

Figure (2) shows statistically significant inverse correlation between duration of exposure in years versus $\mathrm{FVC} / \mathrm{PVC}(\mathrm{P}<0.05)$ 
Table (5) Correlation between blood pressure and PFT versus smoking index among the studied groups

\begin{tabular}{|c|c|c|c|c|c|c|}
\hline \multirow[t]{2}{*}{ Variables } & \multicolumn{2}{|c|}{$\begin{array}{c}\text { Highly } \\
\text { exposed } \\
\text { Smoking index }\end{array}$} & \multicolumn{2}{|c|}{$\begin{array}{c}\text { Moderately } \\
\text { exposed } \\
\text { Smoking index }\end{array}$} & \multicolumn{2}{|c|}{$\begin{array}{l}\text { Unexposed } \\
\text { Smoking } \\
\text { index }\end{array}$} \\
\hline & $\mathbf{r}$ & $\mathbf{P}$ & $\mathbf{r}$ & $\mathbf{P}$ & $\mathbf{r}$ & $\mathbf{F}$ \\
\hline SBP & 0.13 & 0.25 & 0.31 & $0.02 *$ & 0.03 & 0.67 \\
\hline DBP & 0.10 & 0.11 & 0.13 & 0.11 & 0.06 & 0.20 \\
\hline MABP & 0.02 & 0.52 & 0.33 & $0.001 *$ & 0.08 & 0.68 \\
\hline FVC & -0.03 & 0.45 & -0.13 & 0.10 & 0.11 & 0.14 \\
\hline FEV1 & -0.02 & 0.89 & -0.12 & 0.15 & -0.03 & 0.56 \\
\hline FEV1/FVC & -0.09 & 0.32 & 0.15 & 0.10 & -0.15 & 0.10 \\
\hline FVC/PVC & -0.56 & 0.000 ** & -0.29 & $0.02 *$ & -0.31 & $0.01 *$ \\
\hline
\end{tabular}

SPB: Systolic blood pressure DBP: Diastolic blood pressure *: Significant MABP: Mean arterial blood pressure

**: highly significant

Table (5) shows statistically significant inverse correlation between FVC/PVC versus smoking index among highly, moderately and unexposed group. Among moderately exposed group there is a statistically significant positive correlation versus SBP and MABP. 


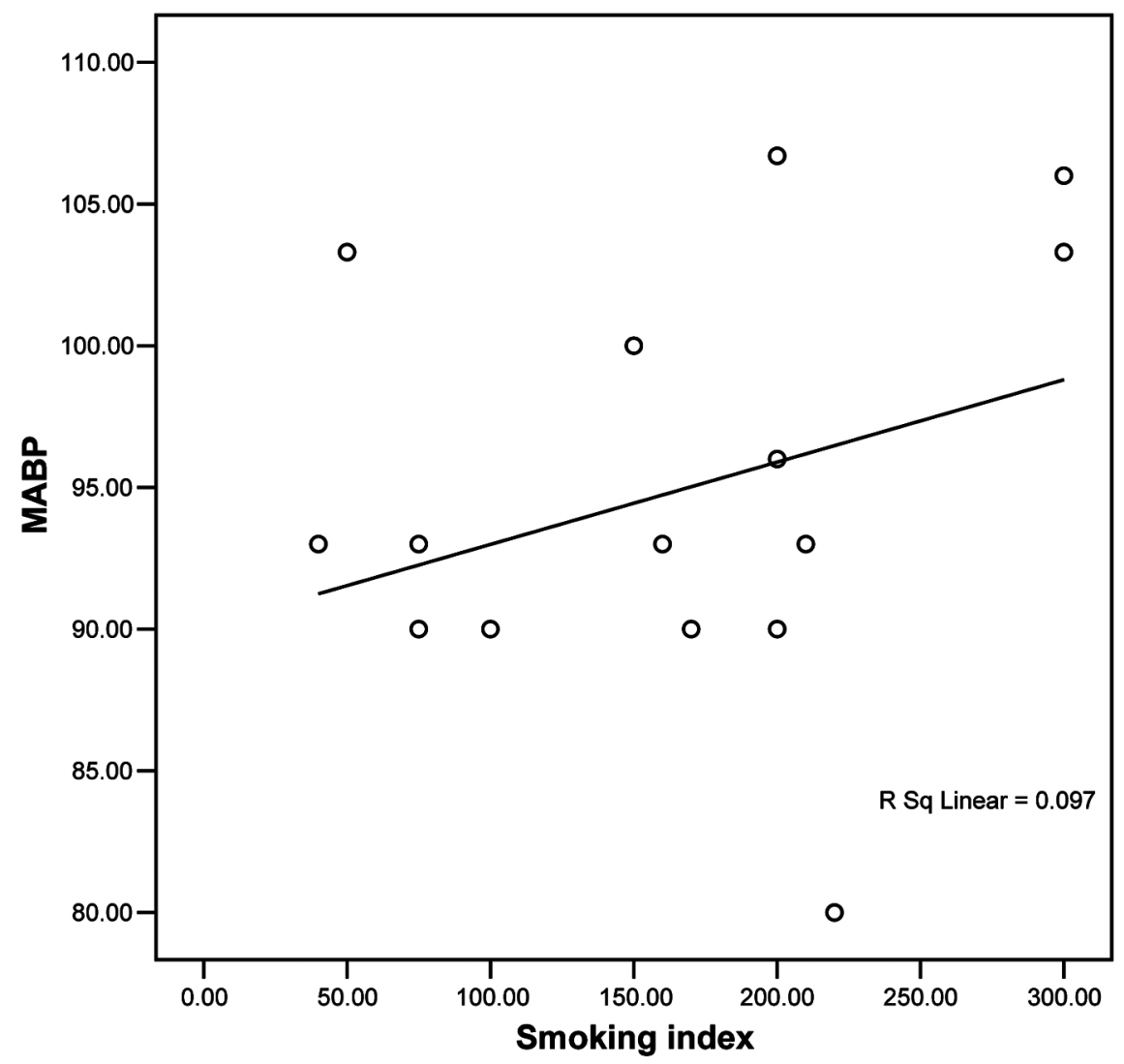

Figure (3) Correlation between smoking index versus MABP among highly exposed group

Figure (3): shows significant inverse correlation between smoking index versus $\operatorname{MABP}(\mathrm{P}<0.05)$ 
Table (6) Relation between blood pressure and PFT versus smoking among each group

\begin{tabular}{|l|c|c|c|c|c|c|}
\hline \multicolumn{1}{|c|}{ LSD } & P & \multicolumn{2}{c|}{$\begin{array}{c}\text { Unexposed } \\
\text { Smoking }\end{array}$} & \multicolumn{2}{c|}{$\begin{array}{c}\text { Exposed } \\
\text { Smoking } \\
\text { No (1) }\end{array}$} & Yariables \\
& & & No (3) & Yes(4) & \\
\hline $\begin{array}{l}1 \text { versus 2\&3 } \\
2 \text { versus 3\&4 }\end{array}$ & $<0.05^{*}$ & $125 \pm 13.6$ & $120 \pm 11$ & $129 \pm 14$ & $124 \pm 10$ & SBP \\
\hline $\begin{array}{l}1 \text { versus 2\&3 } \\
2 \text { versus 3 }\end{array}$ & $<0.05^{*}$ & $79.9 \pm 10$ & $71.5 \pm 8$ & $80 \pm 15$ & $76 \pm 12$ & DBP \\
\hline $\begin{array}{l}1 \text { versus 2\&3\&4 } \\
2 \text { versus 3\&4 }\end{array}$ & $<0.05^{*}$ & $86.5 \pm 13$ & $83 \pm 11$ & $95 \pm 10$ & $91 \pm 14$ & MABP \\
\hline $\begin{array}{l}1 \text { versus2\&3 } \\
2 \text { versus 3\&4 }\end{array}$ & $<0.05^{*}$ & $4.5 \pm 0.8$ & $4.8 \pm 1.1$ & $4.1 \pm 1.5$ & $4.4 \pm 1$ & FVC \\
\hline $\begin{array}{l}1 \text { versus2\&3 } \\
2 \text { versus 3\&4 }\end{array}$ & $<0.05^{*}$ & $3.7 \pm 0.7$ & $3.8 \pm 0.6$ & $3.0 \pm 0.9$ & $3.5 \pm 1.2$ & FEV1 \\
\hline $\begin{array}{l}1 \text { versus 2\&3 } \\
2 \text { versus 3\&4 }\end{array}$ & $<0.05^{*}$ & $83 \pm 20$ & $86 \pm 12$ & $79 \pm 19$ & $83 \pm 15$ & FEV1/FVC \\
\hline $\begin{array}{l}1 \text { versus2\&3 } \\
2 \text { versus 3\&4 }\end{array}$ & $<0.05^{*}$ & $87.4 \pm 18$ & $90 \pm 15$ & $81 \pm 16$ & $85 \pm 20$ & FVC/PVC \\
\hline
\end{tabular}

SPB: Systolic blood pressure

DBP: Diastolic blood pressure

MABP: Mean arterial blood pressure

*: Significant

Table (6) shows that non smoker unexposed group had lower SBP, DBP and MABP compared to smokers exposed with statistically significant difference in between $\mathrm{p}<0.05$.

As regard PFT exposed smokers had lower FVC, FEV1, FEV1/FVC and FVC/ PVC compared to exposed non smoker and unexposed smokers with statistically significant difference. 


\section{Discussion}

This study was performed on 410 workers in carbon black factory in Alexandria , Egypt .The aim of the work was to investigate the respiratory and cardiovascular health hazards due to exposure to carbon black. Carbon black is considered one of the most popular pollutant in Egypt environment and this was the main concept of this thesis to spotlight possible short and long term effects on workers and hence on the general population.

Average age of the studied group was $35.5 \pm 5$ and all of them were males with average duration of employment $7 \pm 3.2$ years. The studied group was classified into 3 subgroups according to the level of exposure to the carbon dust (highly, moderately and unexposed). There is no statistically significant difference between the studied groups as regard age, duration of employment and smoking index.

The current study shows that DBP was higher among highly exposed group ( 80.7 \pm 9 ) compared to moderately exposed (77.6 \pm 9$)$ and unexposed (76.5 \pm 8$)$ with statistically significant difference ( Table1). This agreed with a study done by Gardiner et al, 2001 in Europe on 19 carbon black factories, they found that DBP was higher among carbon black exposed workers $(84.5 \pm 7)$ compared to unexposed group $(75 \pm 4$ ) with statistically significant difference . Several mechanisms were described to explain the pathogenesis of hypertension induced carbon black exposure through the effect on micro RNA genes which claimed to induce hypertension but the exact mechanism were not clearly understood as concluded from Walker et al. 2010.

On the other hand the current study found that mean arterial blood pressure (MABP) was higher among highly exposed (95 18.4$)$ and moderately exposed $(92.3 \pm 9)$ group compared to unexposed group (84.5 \pm 8.6$)$ and also highly exposed departments compared to moderately exposed with significant difference according to post hoc test $\mathrm{p}$ value less than 0.05 as shown in Table 1. These results were similar with a study done by Love et al 2009 which examine the relation between occupational exposure to carbon black among heavy clay industry workers ( 300 workers). They detected that the average MABP among exposed departments like production and preparation were $97.6 \pm 3$ compared to $89 \pm 5$ among clerks in the same factory as a non exposed group 
with significant difference in between both groups. Another study done by Bartoli et al 2009 which supports the direct relationship between higher MABP among carbon black non obese non smoker group compared to matched unexposed group with statistical significant difference $\mathrm{p}<0.05$.

The old explanation of carbon black induced hypertension may be due to atherosclerotic changes that my happen with long term repeated exposure to carbon black especially if associated with smoking. This hypothesis was supported by Mossman et al, 2007 who deduced that inhalation of carbon black about $0.5 \mathrm{ml} /$ day for consecutive days, lead to decline in acetylcholine and atherosclerotic plaque increased in size compared to a low dose exposure of carbon black with no abnormalities could be detected.

On the other hand another mechanism which described vascular changes in relation to other carbon black components as polyaromatic hydrocarbons and benzopyrene by activation of the aryl hydrocarbon receptor and formation of reactive metabolites, both of which lead to increased oxidative stress ( Gentner and Weber , 2011).
As regard radiological findings, lung congestion (increased broncho vascular markings) and cardiomegally were more frequent among highly exposed group compared to other two groups with statistically significant difference Table (2). On the other hand no statistically significant difference could be detected in between the 3 subgroups as regard $\mathrm{CBC}$ and clinical examination. These findings reflected the difficulty in early detection of pulmonary and CVS changes due to vague symptoms and non conclusive clinical findings; so routine plain chest $\mathrm{x}$-ray-is mandatory in addition to pulmonary function tests for early detection of any changes. In a study done by Quanjer PH et al, 2003 in which 350 workers exposed to carbon black are examined in comparison to administrative workers in same factories, he reported that cardiomegally was more frequent among exposed group in comparison to unexposed group. Radiological findings may be explained as back pressure changes due to lung fibrosis although cases may be still compensated not yet evident clinically as heart failure. The current study detected 40 cases out of 350 exposed workers complaining of restrictive lung changes which may be due to repeated inhalation of fine carbon black particles for long duration. 
The current study described the possible effects of carbon exposure on pulmonary functions Table(3) which showed that FEV1 was higher among unexposed group $(3.8 \pm 0.7)$ compared to moderately exposed $(3.5 \pm 0.8)$ and highly exposed group FEV1 was (3.4 \pm 0.9$)$ with statistically significant difference. Also FVC was higher among unexposed group (4.8 \pm 0.7$)$ compared to moderately exposed group (4.6 \pm 0.9$)$ which was slightly higher than highly exposed group $(4.3 \pm 0.8)$ with statistically significant difference. Both FEV1/FVC \% and FVC/PVC \% were higher among unexposed group $(84.6 \pm 7.6)$ and $(89 \pm 7.6)$ compared to heavily exposed $(77.6 \pm 9)$ and $(85.3 \pm 9)$ and moderately exposed $(80 \pm 5)$ and $(87 \pm 7)$ respectively with statistically significant difference. These results agreed with the work done by Alexeeff et al 2007, who tested different predictors of impaired lung function on heavy exposed carbon black workers. Findings described by this study were FEV1 $3.5 \pm 0.8$ compared to $4.1 \pm 0.8$ among unexposed group with statistically significant difference. On the other hand FEV1/FVC in the same study among exposed group was $78 \pm 10$ compared to $85 \pm 13.4$ among non exposed group but no significant difference as regard $\mathrm{FVC} /$
PVC which is slightly lower among exposed group ( $p>0.05$ ). Also our study was concomitant with the study done by Bartoli 2009 who detected that there is a significant decline of $\mathrm{FVC} / \mathrm{PVC}$ among exposed group compared to non exposed group.

As regard the relation between work duration versus blood pressure and pulmonary function tests as shown in Table (4) there is a statistically significant inverse correlation between all PFT versus duration of exposure among highly and moderately exposed group. There is a statistically significant inverse correlation between FVC, FEV1 and FVC/PVC. On the other hand no significant correlation could be detected versus FEV1/FVC. These results agreed with a study done by Tunnicliffe et al, 2005 who reported inverse correlation between FVC versus duration of exposure and $\mathrm{FVC} /$ PVC ratio and FEV1 and these findings indicated that carbon black not only cause lung fibrosis that lead to long term pneumoconiosis as known before but also play an important role in obstructive lung disorders.

Smoking duration and number of cigarettes/day are represented as smoking index which show significant 
inverse correlation between $\mathrm{FVC} / \mathrm{PVC}$ versus smoking index among highly exposed group. Among moderately exposed group there is a statistically significant inverse correlation between FVC/PVC versus smoking index and positive correlation versus SBP and MABP. On the other hand there is inverse significant correlation between smoking indexes versus FVC/PVC among unexposed group as shown in Table (5). These results was similar with a study done by Gardiner, et al 2001 which confirm significant inverse correlation between smoking index and $\mathrm{FVC} / \mathrm{PVC}$ ratio $\mathrm{r}=-0.45$ with $\mathrm{p}$ $<0.05$ and also versus FEV1/FVC $\mathrm{r}$ value $=-0.29(\mathrm{p}<0.05)$. No significant correlation between smoking duration versus systolic blood pressure but significant positive correlation was found versus DBP r value $0.31 \mathrm{p}<0.05$. Smoking duration and amount/day played an effective role in decreasing lung volumes in addition to the cumulative effect on atherosclerotic process and increase mean arterial blood pressure.

As regard the role of smoking, the current study concluded that smoking may play a synergistic effect on both pulmonary and blood pressure changes as shown in Table (6). It is evident that non smoker among exposed group had lower SBP, DBP $(124 \pm 10,76 \pm 12$ respectively) compared to smokers with SBP $129 \pm 14$ and DBP $80 \pm 15$ with statistically significant difference. As regard PFT the exposed smokers had lower FVC $(4.1 \pm 1.5)$ compared to non smoker with FVC $(4.4 \pm 1)$ with significant difference and also FEV1 was lower among smoker group (3.0 \pm 0.9$)$ compared to non smoker . On the other hand there is no significant difference between smokers and non smokers as regard other variables. Also blood pressure and PFT among exposed group irrespective to smoking were worse with significant difference compared to unexposed group and this make spotlight of the synergistic effect of smoking. These results were in agreement with a study done by Simpson et al, 2008 who compare smoker exposed to carbon black versus non smoker and get the same conclusion of possibility of synergistic effect on pulmonary functions and blood pressure. Smoking also may play a role in increasing the intake of carbon black fine particles by inhalation and by contaminated hands; in addition to the atherosclerotic effect of smoke and direct effect on lung parenchyma. 


\section{Conclusion}

Carbon black exposure plays an important role on deterioration of lung functions and elevation of diastolic and mean arterial blood pressure. Duration of exposure and smoking index played an important role on the effect on pulmonary function tests and blood pressure. This reflect the great role of health education for those exposed workers to cover this issue of smoking from this point of view of cumulative effect in addition to their daily exposures which may enhance cardio-pulmonary health hazards.

\section{References}

1. Alexeeff SE, Litonjua AA, Suh H, Sparrow D, Vokonas PS, Schwartz J (2007): Ozone exposure and lung function: effect modified by obesity and airways hyperresponsiveness in the VA Normative Aging Study. Chest; 132(6):1890-1897.

2. Auchincloss AH, Roux AV, Dvonch JT, Brown PL, Barr RG, Daviglus ML, et al. (2008): Associations between recent exposure to ambient fine particulate matter and blood pressure in the multi-ethnic study of atherosclerosis (MESA). Environ Health Perspect; 116:486-491.

3. Baccarelli A, Wright RO, Bollati V, Tarantini L, Litonjua AA, Suh HH, et al. (2009): Rapid DNA methylation changes after exposure to traffic particles. Am J Respir Crit Care Med; 179(7):572-578.

4. Bartoli CR, Wellenius GA, Diaz EA, Lawrence J, Coull BA, Akiyama I, et al.(2009): Mechanisms of inhaled fine particulate air pollution-induced arterial blood pressure changes. Environ Health Perspect; 117:361-366.
5. Brook RD (2008): Cardiovascular effects of air pollution. Clin Sci (Lond); 115(6):175-187.

6. Burt VL, Whelton P, Roccella EJ, Brown C, Cutler JA, Higgins M, et al. ( 2008): Prevalence of hypertension in the US adult population. Results from the Third National Health and Nutrition Examination Survey, 1988-1991. Hypertension; 25(3):305-313.

7. Clinton M (1992): Ph.D, Rebecca G. Knapp: Clinical epidemiology and biostatistics, published by Williams \& Wilkins, Maryland: 3rd edition

8. Gardiner K (2006): Effects on respiratory morbidity of occupational exposure to carbon black: a review. Arch Environ Health; 50:44-60.

9. Gold DR, Litonjua A, Schwartz J, Lovett E, Larson A, Nearing B, et al. (2000): Ambient pollution and heart rate variability. Circulation; 101(11):1267-1273.

10. Harrabi I, Rondeau V, Dartigues JF, Tessier JF, Filleul L (2006): Effects of particulate air pollution on systolic blood pressure: a population-based approach. Environ Res; 101(1):89-93.

11. Küpper HU, Breitstadt R and Ulmer WT (2006): Effects on the lung function of exposure to carbon black dusts. Results of a study carried out on 677 members of staff of the DEGUSSA factory in Kalscheuren/Germany. Int Arch Occup Environ Health; 68:478-473.

12. Gardenier $\mathrm{K}$, van Tongeren $\mathrm{M}$, Harrington M (2001): Institute of Occupational Health, University of Birmingham, Birmingham B15 2TT, UK Occup Environ Med; 58:496503 doi:10.1136/oem.58.8.496.

13. Gentner NJ and Weber LP (2011): Intranasal benzo[a]pyrene alters circadian blood pressure patterns and causes lung inflammation in rats .Arch Toxicol. 85(4):337-46. doi: 10.1007/s00204-010-0589-6. Epub 2010 Sep 17.PMID:20848083

14. Ibald-Mulli A, Stieber J, Wichmann HE, Koenig W, Peters A ( 2001) : Effects of air pollution on blood pressure: a population-based approach. Am J Public Health 91(4):571-577. 
15. Ikeda S, Kong SW, Lu J, Bisping E, Zhang H, Allen PD, et al (2007): Altered micro RNA expression in human heart disease. Physiol Genomics; 31(3):367-373.

16. Jansen KL, Larson TV, Koenig JQ, Mar TF, Fields C, Stewart J, et al. (2005): Associations between health effects and particulate matter and black carbon in subjects with respiratory disease. Environ Health Perspect; 113:1741-1746.

17. Love RG, Waclawski ER, Maclaren WM, et al. (2009): Risk of respiratory disease in the heavy clay industry. Occup Environ Med; 56:124-133.

18. Madsen C and Nafstad P (2006): Associations between environmental exposure and blood pressure among participants in the Oslo Health Study (HUBRO). Eur J Epidemiol; 21(7):485-491.

19. D, Coull BA, Gryparis A and Schwartz J (2007): Mortality risk associated with shortterm exposure to traffic particles and sulfates. Environ Health Perspect; 115:751-755.

20. O'Neill MS, Veves A, Zanobetti A, Sarnat JA, Gold DR, Economides PA, et al. (2005): Diabetes enhances vulnerability to particulate air pollution-associated impairment in vascular reactivity and endothelial function. Circulation; 111(22):2913-2920.

21. Pope CA III, Burnett RT, Thurston GD, Thun MJ, Calle EE, Krewski D, et al. (2004): Cardiovascular mortality and long-term exposure to particulate air pollution: epidemiological evidence of general pathophysiological pathways of disease. Circulation; 109(1):71-77.

22. Quanjer PH, Tammeling GJ, Cotes JE, et al. (2003): Lung volumes and forced ventilatory flows. Report of the working party on standardisation of lung function tests for the European Community for Steel and Coal. Official statement of the European Respiratory Society. Eur Respir J; 6:5-40.

23. Rao PK, Toyama Y, Chiang HR, Gupta S, Bauer M, Medvid R, et al. (2009): Loss of cardiac micro RNA-mediated regulation leads to dilated cardiomyopathy and heart failure. Circ Res; 105(6):585-594.
24. Rich DQ, Schwartz J, Mittleman MA, Link M, Luttmann-Gibson H, Catalano PJ, et al. (2005): Association of short-term ambient air pollution concentrations and ventricular arrhythmias. Am J Epidemiol; 161(12):1123-1132.

25. Schwartz J, Litonjua A, Suh H, Verrier M, Zanobetti A, Syring M, et al. (2005): Traffic related pollution and heart rate variability in a panel of elderly subjects. Thorax ;60(6):455-461.

26. Simpson JCG, Niven RM, Pickering CAC, et al. (2008): Prevalence and predictors of work related respiratory symptoms in workers exposed to organic dusts. Occup Environ Med; 55:668-672.

27. Suarez Y, Fernandez-Hernando C, Pober JS, Sessa WC (2007): Dicer dependent micro RNAs regulate gene expression and functions in human endothelial cells. Circ Res; 100(8):1164-1173.

28. Suarez Y and Sessa WC (2009): Micro RNAs as novel regulators of angiogenesis. Circ Res; 104(4):442-454.

29. Szozda R (2005): The circulatory system in workers involved in carbon black production. Medycyna Pracy; 45:405-410.

30. Tunnicliffe WS, O'Hickey SP, Fletcher TJ, et al. (2005): Pulmonary function and respiratory symptoms in a population of airport workers. Occup Environ Med; 56:118-123.

31. Zanobetti A, Canner MJ, Stone PH, Schwartz J, Sher D, Eagan-Bengston E, et al. (2004): Ambient pollution and blood pressure in cardiac rehabilitation patients. Circulation; 110(15):2184-2189.

32. Van Tongeren MJA, Gardiner K, Kromhout H (2000): Trends in levels of inhalable dust exposure, exceedance and overexposure in the European carbon black manufacturing industry. Ann Occup Hyg; 44:271-280.

33. Wilker EH, Baccarelli A, Suh H, Vokonas P, Wright RO and Schwartz J (2010): Black Carbon Exposures, Blood Pressure, and Interactions with Single Nucleotide Polymorphisms in Micro RNA Processing Genes. Environmental Health Perspectives; 118(7): 943-94. 